Rural Sociology 65(3), 2000, pp. 357-375

Copyright $\odot 2000$ by the Rural Sociological Society

\title{
Maintaining Solidarity: A Look Back at the Mormon Village*
}

\author{
Todd Goodsell** \\ Department of Sociology and \\ Institute for Social Research \\ The University of Michigan at Ann Arbor
}

Abstract The present study suggests, in contrast to community dissolution theories, that community is maintained through a dialogue between ideological commitment and cooperative action within a cultural framework. The research follows up on a classic rural community study series, that of Lowry Nelson's Mormon villages. Replicating Nelson's ethnographic methods, the author reevaluates the earlier findings and extends the data by several decades. Nelson's findings on Mormon village dynamics are still relevant, although in modified forms, largely through community members' commitments to a common ideology. The author concludes that affectively based communities persist despite modernization. Mormon solidarity has endured because of its early articulation of expected interaction with the broader social world and because of its commitment to both ideals and practical action.

Community and solidarity have figured prominently in sociological theorizing for more than a century. Indeed, one writer recently named solidarity "sociology's most revered topic" (Lindenberg 1998:61). Familiarity with Durkheim's (1964) writings on mechanical and organic solidarity has become a rite of passage for aspiring American sociologists.

Fewer sociologists are so familiar with the literature on community, although its history is at least as long. American rural and urban sociologists began to study community in earnest at the turn of the twentieth century, with a number of community studies that became classics. One of these-Lowry Nelson's Mormon village series -is often remembered for its integration of these two critical concepts. Nelson observed that the Mormon village is remarkable for its high degree of community solidarity. Because the literature suggests that viable and enduring social solidarity is rarely achieved and even more rarely maintained in the modern world, it seems important to understand the cultural dynamics that lead to this noteworthy outcome.

\footnotetext{
* The author gratefully acknowledges the advice of J. Lynn England, Carol J. Ward, Howard M. Bahr, Arland Thornton, and the anonymous reviewers. An earlier draft of this paper was presented at the annual meetings of the Rural Sociological Society, held in Portland, Oregon in August 1998.

** Please direct correspondence to the author at Department of Sociology, $500 \mathrm{~S}$. State, 3012 LS\&A, Ann Arbor, MI 48109-1382.
} 
Most community studies have taken as their theoretical orientation some form of modernization theory-what Stein (1972:5) breaks down into "urbanization, industrialization, and bureaucratization." Building on the grand narrative of modernity, these studies chronicle the transition of human society, for better or worse, from an agricultural, rural, local, kinship-based structure to a structure featuring all of the urban, industrial, rational, and extralocal linkages of the contemporary developed world. This is not to say that community sociologists have ignored the continuing role of nonrational, local, and kinship structures in community life, but these are often viewed as relics of an earlier time, anomalies which themselves need to be explained. Generally the narrative given is that of community dissolution: the workings of modernity act against "community," defined as a nonrational element that characterized earlier periods of human history.

The community dissolution hypothesis generates an irony, however, that has yet to be fully explored: if we arranged most community studies chronologically by the period of time examined, and charted the narrative of community found collectively in those studies, the story would read that first there was community ... and then it collapsed, and it collapsed, and it collapsed, and so on. Only occasionally do we find the story of community building: that at certain times, a group of people collectively define a reality greater than themselves, and take whatever action is necessary to make that reality effective in their lives. It is odd that theory and research should focus so strongly on the fall of community, because it does not seem far-fetched to suggest that every fall of community must have been preceded by a rise. And in a practical sense, it would seem that understanding the mechanics of that rise would be more useful for someone seeking to attain or improve the positive aspects of community in social life.

The discussion described above, of course, presupposes that community is cyclical: it must be either rising or falling. The necessity of experiencing only the one or the other is still unproved in the sociological literature. Moreover, the nature of community maintenance is underdeveloped.

The Mormon village (as Lowry Nelson titled his two series of rural community studies completed respectively in the 1920s and in 1950) provides at least a partial answer to the omissions of other community research. Nelson's writings on solidarity focus on its formation. He found that a strong sense of social solidarity was fostered by four social factors in the Mormons' early experience: charismatic leadership, an inclusive, millennialist ideology, conflict with those not of their faith, and cooperation among themselves to colonize the West. Writing of his resurvey of the Mormon village, Nelson (1952) concluded that solidarity had declined because of local 
residents' increased independence and the Mormon villages' increased involvement with the larger society.

Nelson's conclusion of solidarity decline may have been mistaken, however. The first reason for this is that the definition of solidarity was not held constant across the two series: in the first series, solidarity seems to be defined by affect, but in the second series it is defined as behavior. A second reason is that Nelson's study of solidarity did not take into account the changes in historical circumstances. At particular times in the history of a people or a place, solidarity may need to be understood or expressed in different ways.

In the present research I seek to address these problems in three ways. First, I attempt to construct a definition of solidarity currently applicable to the study of the Mormon village. Second, I attempt to investigate Nelson's original four elements promoting solidarity, to evaluate how they might still apply to the social life of the locality. Third, I attempt to outline some additional elements in the social life of the Mormon village that might lend themselves to the maintenance of solidarity. This research is comparative, but not in the sense more common today in community studies. This research is comparative across time rather than place: I compare a single locality, one of the classic "Mormon villages," at different points in time in order to understand its internal cultural dynamics.

\section{Theories of Community and Solidarity}

Marx and Engels (1970:83) made community the critical objective of social relations. They wrote, "Only in community [with others has each] individual the means of cultivating his gifts in all directions; only in the community, therefore, is personal freedom possible." They explained that the division of labor known in the contemporary West grew from simple physical and biological facts, but once established it became coercive toward its creators. Ultimately, they predicted, this coercive division of labor would be overthrown, but only when a threshold of consciousness (a conceptual precursor to solidarity) was reached. Community based on consciousness is the means by which people will accomplish solidary goals previously hindered by class divisions.

Considering the same problem-division of labor-but interpreting it differently, Durkheim (1964:56) explained that the modern division of labor has a moral effect on individuals; this in turn engenders a "feeling of solidarity," which he seems to define as "relations of friendship." Defining solidarity as moral and affective, however, presents some challenges to empirical research, so Durkheim proposed the study of law as a visible symbol of solidarity.

By selecting a behavioral measure of an affective phenomenon, Durkheim opened himself to criticism. Pope and Johnson (1983:682), for example, wrote, "Solidarity [to Durkehim] presum- 
ably refers to the mutual coordination of units and their integration into some larger whole." They observed that Durkheim abandoned the distinction between mechanical and organic solidarity after publishing his Division of Labor in Society, and opted instead to center his explanations on common sentiments and beliefs. Pope and Johnson charged that this constitutes a radical departure from Durkheim's earlier work. This is a radical shift, however, only if one neglects Durkheim's comments about solidarity as friendship and affective bonding - that which underlies the overt coordination of action. The problem is inherent not in his theory, but in his measurement.

Hechter (1987) rejected normative, structuralist, and functionalist definitions of solidarity in favor of what he considered a more falsifiable definition grounded in rational choice theory. He asserted that solidarity was found in predictable behavior patterns on the basis of whether exchange occurred or was even possible.

Lindenberg (1998) found Hechter's assumptions feasible but theoretically unsatisfactory, and proposed his own theory of solidarity based on behaviorist-rational choice principles. He defined solidarity as behavior toward common goals, and as based on a preference for long-term over short-term goals. Because people tend toward myopic opportunism, maintenance of solidarity must center on sustaining frames congenial to long-term referents. Such referents would seem to be more stable in macro structures than in micro foundations; hence the importance of social compositions such as states and communities in maintaining solidarity.

As welcome as such a well-developed theory of solidarity may be, it does not fulfill its own promise of being based purely on behavior, not on affect. The presence of concepts such as goals and preferences suggests that an affective component is assumed, and the need for the articulation of solidary frames implies human actors' inherent subjectivity.

Allen (1999:109-10) unified these lines of theorizing in her recent work. She defined solidarity as "collective power . . . that is achieved through a mutual promise or shared commitment to act in concert, not an exclusionary unity that is presumed in advance." Thus, to Allen, solidarity is continually created and recreated through the union of commitment and action. This solidarity sustains community.

Community maintenance itself has made important inroads into sociological research. Although Fischer (1982) depended heavily on social connections as indicating community, his introduction of culture suggests the need for further research on the role of ideas in the maintenance of community. Brown, Geertsen, and Krannich (1989) and May (1994) introduced longitudinal methods and perspectives, and found that the commitment to ideas and principles 
was the critical element in the ability of Mormonism to maintain community through broad social change.

Because this study builds on Lowry Nelson's work, it is important to understand how he saw community. While conducting the first Mormon village series, Nelson found that these particular villages experience community in a way that reaches beyond a basic definition of community (Nelson 1925). Specifically, he found that "[i]n all cases the [Mormon] village is associated with communism and compact social solidarity" (Nelson 1930:13).

Unfortunately, Nelson did not offer a clear definition of what he meant by solidarity. He showed, however, that certain social processes "[cement] the members of the Mormon group to each other" (1930:27). The solidarity of the Mormon village grows out of these experiences, he hypothesized. Yet the most Nelson does to define solidarity is to call it "intensity of group feeling" (1930:21).

Nelson seems to be an early writer who considered both action and affect in his treatment of solidarity. Like Allen, who views solidarity as the result of the commitment to act, Nelson observed that solidarity actually resulted from action. (The commitment to act presumably preceded the action, as explored in greater depth by Ericksen [1922]).

\section{The Mormon Village}

The Church of Jesus Christ of Latter-day Saints (sometimes abbreviated "the LDS Church" or nicknamed "the Mormon Church") began in 1830 in upstate New York. Under Joseph Smith, Jr., the first leader, the church's membership grew rapidly from its inception. Because of the group's beliefs and behaviors, however, including certain communalistic practices, it was rejected by the larger culture of the American frontier. In 1844, upon Smith's death, Brigham Young assumed leadership and headed a move to the arid West. There, in what can be called the first Mormon diaspora, Latter-day Saints established nucleated settlements from southern Alberta to northern Mexico, with Utah as the geographic hub. ${ }^{2}$

\footnotetext{
${ }^{1}$ The Church of Jesus Christ of Latter-day Saints objects to using terms like "Mormon" and "LDS Church" to refer to itself or to its members, on the grounds that they can be misleading. (Preferences are given in the organization's official website, www.lds.org [accessed 28 April 2000].) I use "Mormon" as a socio-cultural construct that broadly refers to those groups, people, and ideas that can claim a heritage from Joseph Smith, Jr. It does not necessarily refer to any particular church. I use "LDS" to refer to The Church of Jesus Christ of Latter-day Saints and its members. My usage generally agrees with that of residents of the Mormon village.

2 The second Mormon diaspora, largely a post-World War II phenomenon, involved the transformation of Mormonism from a movement bounded by the arid North American West into a worldwide faith. The Mormon village is a unique product of the first Mormon diaspora, not of the second.
} 
Charles Galpin (1924) suggested that Mormon villages have avoided several of the problems that plague other American rural communities because of their remarkable cohesion. Galpin encouraged Nelson to perform empirical work on Mormon villages, and took an advisory role in the subsequent study series (Nelson 1985).

Ericksen contributed much to Nelson's early theoretical orientation regarding Mormon social life by pointing out the relevance of affect in Mormonism. He wrote that to understand "the true meaning of Mormonism we must go to its group sentiments" (Ericksen 1922:8; emphasis added). Mormonism fostered a unity between the individual and the group, in a practical confounding of individual with group interests. In Ericksen's view, solidarity became the foundational Mormon social ethic; as noted elsewhere (Arrington 1958), Mormon solidarity became a primary facilitator for effective instrumental leadership.

Nelson provided the basic outline explaining how the early Mormons were able to develop such solidarity. He suggested that it resulted from four main factors: the charismatic leadership of Joseph Smith and Brigham Young; a shared experience of conflict or outgroup persecution; the history of cooperation that was necessary in order to settle the Rocky Mountains; and a shared millennial vision-that is, a shared set of principles that focused on a common eschatological purpose. When Nelson (1952:137) wrote of his findings from his second, follow-up series on the Mormon village, he concluded that "as the settlement grew and the people began to feel secure, the original motivation for cooperative activity seemed to weaken and the system of competition took its place" (p. 137).

This model, however, contains two major problems. First, of the four factors that promoted solidarity in the first place, the first three-leadership, conflict, and cooperation-are historically specific. If these are the sole bases for solidarity, they must necessarily have declined as those who lived through the formative years of Mormonism gradually died off. Second, Nelson moved away from the idea of solidarity based on affect or sentiment; in his second series, he focused instead on "cooperative activity," a more economical and more organizational approach to the concept.

To address these problems, the present study has three objectives: to develop a definition of solidarity grounded in the Mormon village; to evaluate, in the contemporary village of Ephraim, Nelson's four factors promoting solidarity; and to identify ways in which Ephraimites maintain solidarity over time.

\section{Methods}

Because this study is a follow-up to earlier research, it is important to understand how Nelson conducted his original project. Nelson's Mormon village series consisted of three villages in Utah: Escalante, 
Ephraim, and American Fork. I decided to focus this project on only one of these villages, and selected Ephraim. Significantly, Nelson left the fullest documentation of methods for the Ephraim study. The survey sheets he used in his 1925 study of Ephraim, which are archived at Brigham Young University, indicate that his conclusions on community solidarity were derived not from the survey but from other, qualitative methods.

The second reason why I selected Ephraim was that this work is intended as a baseline study with which to compare American Fork and Escalante. Ephraim is located at the center of the cultural heartland of the first Mormon diaspora (Francaviglia 1978). Although Mormon village solidarity may not be challenged most seriously here, Ephraim offers a superior context for a baseline study examining how solidarity can be preserved, and as a basis of comparison with other villages.

Nelson used multiple methods during the original Mormon village series, including a census of households, long interviews, and reference to histories and administrative records (Nelson 1933). Because his survey schedules do not contain measures of solidarity (Nelson n.d.), it seems reasonable that conclusions related to solidarity resulted from his qualitative methods, and that a follow-up focusing on solidarity should follow a similar plan. Most or all of the fieldwork in any given village apparently was performed by one of Nelson's students at Brigham Young University in brief but intensive investigations during summer months (Nelson 1925, 1933, 1985).

Following Nelson's method, I lived in Ephraim for four weeks during the summer of 1997. Although I used all of the qualitative methods named by Nelson, I considered interviews with local residents the most valuable sources for culturally appropriate interpretations of local activities and identity. I acquired informants using a modified "snowball technique," entering into acquaintanceship networks and asking for references. When I asked for references, however, I explained specifically that I wanted to capture the perspectives of all groups in the town. Thus I deliberately sacrificed proportionality for diversity, as a particular challenge to a theory of solidarity. Insofar as such a theory would result, it would be stronger if I had worked within a sample in which dissenting opinions are maximized.

Some demographic comparisons can be made by using Nelson's (1928) data and those of the 1990 Census (U.S. Department of Commerce 1990). In the mid-1990s, Ephraim was approximately twice as large as in the mid-1920s (see Table 1), but it has largely maintained the look of a Mormon village as a relatively dense cluster of homes and businesses surrounded by open farm and grazing land. Nevertheless, Ephraim today is hardly a farming village: from 1925 to 1990 the proportion of employed persons in the town 
Table 1. Population Change in Lowry Nelson's Mormon Villages

\begin{tabular}{cccc}
\hline Year & Escalante & Ephraim & American Fork \\
\hline 1860 & n.a. & 910 & 695 \\
1870 & n.a. & 1,167 & 1,145 \\
1880 & 623 & 1,698 & 1,299 \\
1890 & 506 & 1,800 & 1,942 \\
1900 & 650 & 2,086 & 2,732 \\
1910 & 846 & 2,296 & 2,797 \\
1920 & 1,032 & 2,287 & 2,763 \\
1930 & 862 & 1,966 & 3,047 \\
1940 & 1,106 & 2,094 & 3,333 \\
1950 & 773 & 1,987 & 5,126 \\
1960 & 702 & 1,801 & 6,373 \\
1970 & 638 & 2,126 & 7,713 \\
1980 & 542 & 2,810 & 12,417 \\
1990 & 818 & 3,363 & 15,696 \\
1997 (est.) & 901 & 3,856 & 20,094 \\
2000 (est.) & 1,063 & 4,196 & 21,675 \\
\hline
\end{tabular}

Sources: Bureau of Economic and Business Research (1996); Moffat (1996); Population Projections for Utah's Cities and Unincorporated Areas (1997).

working in agriculture declined from 60 percent to 8 percent. Much of this change is due to changes in the structure of industry and in the growth of a public two-year college in town. Ephraim residents are better educated than Utah residents are in general, but in 1990 Ephraim had one of the highest unemployment rates in the state, and one of the lowest median incomes. More than 28 percent of Ephraim residents were living below the poverty level, compared with about 10 percent of Utah residents overall.

In 1925, nearly all of Ephraim's residents were white; 10 percent were immigrants from Scandinavian countries. By 1990 Ephraim's population was only 89 percent white, non-Hispanic. The remaining 11 percent were divided about evenly between Hispanic (mostly Mexican-American) and Asian/Pacific Islanders. Because nearly all of the Mexican-Americans in Ephraim are Catholic and nearly all of the European-Americans are Latter-day Saints, ethnic and religious differences are easily confused. An independent Church of the Bible, established only recently and claiming only a few dozen adherents, completes the list of local religious congregations.

Although the Catholic Church and the Church of the Bible are fledgling organizations in Ephraim, the establishment of (apparently) permanent non-Mormon congregations prompted an identity crisis in this Mormon village, and residents are still struggling 
to understand the change. In 1925 , virtually all Mormon villagers were Mormon. Thus the present research must be defined as a study of the Mormon village or of the Mormon village, a task that would have been unnecessary for Nelson. Here I discuss universal representations of concepts as they confront all members of the local society. Not all Mormon villagers are Mormon any longer, but all act daily in a context established by the original Mormon settlers and still dominated by Mormonism.

I conducted long interviews with 52 residents of Ephraim, and obtained demographic information for each. These profiles indicate that the following socioeconomic categories are represented in the informant pool: non-Mormons, nonwhites, non-English speakers, persons involved in agriculture, and persons not born locally are present in greater proportions than in the local population.

\section{Results}

\section{Solidarity Defined}

The first objective of the study was to determine a locally based definition of solidarity. Nelson asserted that solidarity is the defining characteristic of the Mormon village in spite of religious, linguistic, ethnic, and economic divisions. Informants likewise did not accept the mere existence of disparate social categories as grounds for rejecting the label solidary. When asked to define solidarity, their answers suggested an affective attachment to a common purpose:

If I had solidarity with someone, I would think that we would have a commitment, or if with a group, commitment and a common purpose.

Solidarity . . I would use that word to describe a faculty who's united. That we all have similar goals for the purpose of the program - that it was "our" program, not "his" program. ... I'd say that you could apply that to Ephraim, providing all the factions in the community were solid and united on some agreed-upon, mutual goals.

Informants' responses indicated that solidarity in the Mormon village refers to feeling or internal commitment, not usually to interaction or overt coordination of behavior. The informants do not generally believe that solidarity means sameness, whether in behavior or in opinion. The great majority agreed that Ephraim is labeled correctly as solidary.

\section{Factors of Solidarity Transformed}

The factors that led originally to solidarity have been transformed by Mormon villagers so as to apply to changing social and histori- 
cal circumstances. Thus, contrary to the original hypothesis, the factors that created solidarity do not simply become irrelevant once solidarity is established.

Leadership. Joseph Smith and Brigham Young have faded into the background somewhat in daily life in the Mormon village. Their names still are widely recognized, and Mormon villagers realize that many of their social circumstances are due to the actions of these two men, but their present influence is mostly indirect.

Logically, one might ask whether Gordon B. Hinckley, currently president of The Church of Jesus Christ of Latter-day Saints, plays the same social role as did his predecessors in that office. Such a position is difficult to confirm. Arrington (1958) wrote that Brigham Young exerted extensive spiritual and temporal control over early Mormon group life; today it is difficult to find such control exercised by any one person over social life in the Mormon village. True, Hinckley receives much attention and respect. At nearly all of my interviews, for example, several books were present. One such book was Go Forward with Faith, the recently published biography of Hinckley. It was often displayed prominently (frequently face up on the living room coffee table), and I never saw a dusty copy. This was true even in July, when there was no general lack of dust, and even when other material next to the book was dusty.

In terms of practical action, however, Hinckley's leadership does not fit into the same category as Young's. The late twentieth century was not an era of physical colonization. Prophetic calls to action do not generally come as large-scale, group events. Usually they occur individually and do not require sudden, major lifestyle changes such as leaving one's comfortable urban home to become a subsistence farmer on the bank of a muddy creek in Nevada, as at the height of the first Mormon diaspora.

Local ecclesiastical leaders, however, possess a good measure of autonomy. They control the content of meetings, organizational staffing, disciplinary action, and counseling of members. When I was in Ephraim, a house caught fire while the couple who owned it was away. One of the first persons informed was the stake president (a prominent, local religious officer in the LDS Church), who gave attention to the other family members' safety, to the extent of the damage, and to notifying the couple of the incident. Religious leadership remains a cohesive element, but that cohesion is promoted by the coordinated action of local religious leaders and religious leaders at Church headquarters.

Ideology. Nelson (1930) noted the social significance of Mormonism's inclusive and egalitarian system of doctrine. Shepherd and Shepherd (1986:126), in analyzing public Mormon rhetoric, observed that early Mormon discourse focused extensively on its own form of millennialism, an eschatological structure that pre- 
scribed several specific actions for believers such as gathering to "Zion," building temples (houses of worship regarded as much more sacred than common chapels), and proselytizing. They added, however, that the twentieth century had seen "a dramatic decline in persecution and utopian themes associated with the Mormons' nineteenth century conceptions of a literal, material Zion and the eschatological Kingdom of God on earth." This does not necessarily indicate a reversal or hedging of traditional Mormon belief: it may be that these doctrines are less often repeated explicitly because they have become so well established in Mormon thought that they do not need constant reintroduction.

On the basis of field notes I took while in residence in Ephraim, I compared the doctrinal presentations in the primary worship services of one congregation in each of Ephraim's three resident churches: LDS, Catholic, and the Bible Church. I found a certain pattern in the role of doctrine in religious discourse. Latter-day Saint speakers did not necessarily expound doctrine more than those of other denominations, but they showed a greater propensity to link doctrine with practical admonition-and a great deal of that.

Conflict. Ericksen (1922) explained that Mormonism had passed beyond the period of outright persecution, but that the effects remained:

Although the great conflict with the Gentiles practically ended with the expulsion from Nauvoo, its psychological effect still remains and functions vitally in the life of the people. The struggle was too intense and the emotional excitement too great to be quickly eliminated from their consciousness. There is a tendency to rehearse this great conflict in their religious services. (p. 30)

Persecution is more a metaphor than a material reality for people in this Utah town. As noted, however, it is a strong metaphor. One point at which this metaphor is revived is at a Mormon missionary farewell, a church service at which a missionary about to leave for his or her assignment and members of the missionary's family are assigned to speak. The emotion and the imagery of the meeting bear some similarity to sending a young person into conventional warfare. This metaphor underlying missionary service suggests that Mormons still believe in a clear, significant conflict between their religious beliefs and practices and those found elsewhere.

One may question, however, why such a belief should lead to solidarity. Nelson (1930) assumed that a group's common experience of conflict with outsiders will lead to solidarity, but I found some evidence in Ephraim that the causal relationship is not so simple. One Ephraim resident told me: 
I was born in [a non-Mormon city in the West], and there was a great deal of anti-Mormon sentiment there. We were really persecuted. . . . It was so anti-Mormon when I was there, so there wasn't a unity there, except in our little LDS membership. We were very united. Wonderful!

When I asked whether this unity was due to the anti-Mormon pressure, her answer was quick and sure:

No! It was because we were so firm in the faith!

The informant seemed to assume that solidarity results from conflict only in the presence of ideological commitment; without that commitment, external pressures would cause the group to dissolve. She attributed solidarity to intrinsic rather than extrinsic factors. Ericksen (1922) developed this perspective much more fully than did Nelson (1930).

Cooperation and the environment. Nelson (1930) explained that cooperation is necessary for coping with the challenges of the natural environment. It is the only mode of survival when a large group arrives on the frontier and suddenly is required to build roads, irrigation canals, and houses, and to establish manufacturing and merchandising.

Once this work is accomplished, however, such cooperation is not usually necessary to sustain life. Unlike cooperative projects undertaken during the settlement period, a contractor hired by the city performs today's public works, such as the recent paving of the streets. Most residents have no involvement except to vote for or against the project, and then either to enjoy paved streets or to complain about the expense, lament that the roads were left torn up all winter long, and point out that even paved streets develop potholes.

Although cooperation is usually not an environmental imperative, my informants often cited one event in which cooperation was vital to managing an environmental threat: the town's response to the flooding of 1983. In that year, the amount of snow in the mountains was larger than usual. Then came a sudden warming trend, which could have brought a flood within days. Residents met and discussed their options. The possibility that seemed best was to divert Ephraim Creek south of town, but that would have caused some damage to farmland. One informant said:

Discussion was held for maybe half an hour. A proposition: we could do this or we could do this, and this would create this problem and this will create this problem. And ... one of the men whose land this water was going to run all over-he was not going to have a crop that year because it was going to inundate his farming area- ... stood up and said, "If this is what needs to be done, let's get to it!" That 
was so exciting to me to see those people come together like that. I guess that's solidarity . . . I get really emotional about it because I was there and participated in it, and it was exciting. There's another big ditch over here on the north side of town, and there were a couple of homes that were in danger there. Kids were getting up at six o'clock in the morning, going down here to the parking lot behind the library, filling sandbags. Farmers, everybody-six o'clock in the morning-were loading trucks, taking them up, and banking those ditches so those people wouldn't have damage to their homes. . . . You know, not everybody would do that. But the whole community turned out. It was just exciting.

This narrative agrees with the glamorized accounts of the Mormon pioneers conquering the wilderness through selflessness, hard work, and cooperation. Yet this was the only incident described to me in which the natural environment presented a major threat to the group, and the group pulled together and cooperated completely to protect life and property. On one hand, such experiences leave a clear and lasting imprint on a community's consciousness, thereby providing the members of the community with evidence contributing to their group identity. On the other, this event does not characterize the common, day-to-day experience of living in the community.

In the Mormon village, the environment also has come to be appreciated for its aesthetic and recreational value (as in many rural parts of the United States). More than that, it has become an icon of commitment and of local identity and values. This is the case because a group's relationship to its environment is never a given. Indeed, space is a tool always available for appropriation and reinterpretation (Lefebvre 1976). When Mormons left the populated East, they could have defined the Western frontier ahead of them as a dark wilderness, the undesirable land of exile, and evidence of God's displeasure toward them (or at least of His neglect). Instead, although they call this region a "desert," they emphasize the moral symbolism and the moral growth that comes from interaction with the desert. One informant told me:

So I think this valley is a pretty hostile valley as far as climate is concerned for crops and livestock. We have harsh winters and we don't have much water, but that may not be bad because it produces people with strong wills and strong commitments.

The belief in the moral symbolism of a harsh environment is echoed in Mormon hymns: 
Firm as the mountains around us,

Stalwart and brave we stand

On the rock our fathers planted

For us in this goodly land-

The rock of honor and virtue,

Of faith in the living God.

They raised his banner triumphant

Over the desert sod. (Hymns of The Church of Jesus Christ of

Latter-day Saints 1985:no. 255)

\section{Additional Factors in Solidarity}

Ephraimites have established a set of norms that seem capable of perpetuating a sense of community, if used properly. These concern gossip, service, and identity or heritage. Any of these, in fact, could be divisive for residents of Ephraim, but in general they seem to be applied so as to exert a positive effect on community life.

Gossip. Residents of Ephraim are aware that gossip can be very harmful, but they also recognize that it can be a tool for good. The difference seems to be that harmful gossip focuses on another person's character, reinforces negative stereotypes of a person or group of people, does not propose or expect action to be taken to resolve the problem, and separates the person delivering the gossip from the person or activity that is the subject of gossip.

The model of positive gossip in Ephraim appears to work as follows. Somehow somebody tells you about a problem that someone else is facing. You duly express concern for that person. Then you evaluate how you can help. If there is something you can do, you do it. If there is not, you pass the story along to someone else in the hope that before too long the gossip will reach someone who can help the distressed neighbor. From what I learned, the response time is usually short. To learn of someone else's need and to be able to help, but to neglect to do so, places a person in violation of community norms. Stories of spontaneous aid rarely cast the storyteller in the role of the person providing the aid.

In certain instances, local norms of gossip clash with policies of the LDS Church. Mormons have a strong sense of justice. Even though their doctrine indicates that much justice must wait to be served until after this life, and even though LDS doctrine also contains a strong element of mercy, Mormons like to see the "end of the story," when the victims are vindicated and the evildoers are punished. It is not LDS policy, however, to support local gossip circles. Some misbehavior is handled in private councils and interviews; that treatment is indicated to be sufficient ecclesiastically. LDS policy and local culture are not yet reconciled in this respect.

Because of the language barrier, the Spanish-speaking minority is 
almost entirely cut off from positive gossip circles. Gossip circulates about them, but it is quite ill informed and general, and it does not allow for positive action because it does not identify a person who could be helped. The rhetoric in English-speaking Ephraim isolates the Spanish-speaking minority with vague generalizations that do not suggest any inclusive course of action.

Service. Successful, positive application of norms of gossip depends on successful, positive application of norms of service. If no one takes action to change local circumstances, gossip becomes a social liability. If service is to be a cultural element like gossip, common and always ready, it should characterize everyday life rather than only a few scattered crises. Unfortunately, anecdotal evidence is inadequate to assess the pervasiveness of service and the scale on which it occurs. One informant commented:

We saw it, I think, on Saturday when we were out at the park [doing a group service project]. It's amazing how many people came up to me and said, "Why don't we do this more often?" We need this, and we're losing a sense of community when we don't do these things. Service is probably the area that brings it out the most.

Some residents criticize the local culture for not integrating service fully enough into its daily life. Others assert that it is always there, but is so common and so quiet that many people do not notice it. One informant strongly rejected the notion that people in Ephraim serve only in times of crisis. As a counterexample, he told me that his family and the next-door neighbors have a "running competition" to see who can take out each other's trash first on garbage day.

It seems that service is valued in all cases and is appreciated when it is rendered. When people talk about service, occasional expressions of guilt for not doing more are further indications that service is a relevant community norm.

Heritage. O'Dea (1957) saw elements of an incipient Mormon heritage movement in his often-cited analysis of Mormonism. Local heritage activities in Ephraim focus on the settlement period. Principles taught through stories include religious connections, spending time with family, working hard, being internally committed to a principle, and being committed to one another.

However, the awareness of local heritage in Ephraim and the taking of concerted action on its behalf seem to postdate the second Mormon village series. The narrative centers on the Ephraim Tabernacle, which was destroyed on Saturday, April 5, 1952. One informant told the story as follows:

We just felt like it was a tragedy because when we moved here [in the late 1960s] all we heard was people moaning 
because they lost their tabernacle that was over there. You probably heard a lot about the old tabernacle. It was just one of those sad things at that time. The [LDS] Church thought they had to build the new building in the same place as the old one and tear it down. ... Well, it wasn't adequate for the modern usage, ... like the buildings are now. Of course, the one in Manti, they added on [thereby preserving the Manti Tabernacle]. . . . But this was in the 1950 s, I guess . . . A lot of people in town tried to save it, but just had the idea that if the Church says "Tear it down," that must be direct revelation so we'd better do it. . . . It was a mess, and we decided that the Church Building Committee wasn't really acting on direct revelation sometimes with their decisions. I shouldn't be talking about those kinds of things, I guess.

[Interviewer]: Someone told me that the reason they tore it down was because they discovered a few cracks in the foundation. ...

Well, yeah, but when they tried to get it down, they had to dynamite it and one rock fell across the street and they couldn't dynamite that thing, it was so sturdy. . . Y Yeah, see, that was just a poor excuse so they could tear it down. Because it was easier to build a new one there, but ... I don't know. It's just a different mindset now. Fortunately, they've changed their activities.

[Interviewer]: So now the co-op is the main building with historical significance.

Yeah, the only one left in Ephraim because the college has expanded and torn down so many of the old, historic homes, and really there just wasn't anything left. And we just felt like we can't lose that one, too. So we got busy and did what we could. And it was enough to save it.

Several versions of the narrative maintain the "one rock," which was all that blew off the supposedly unsound structure upon the first detonation. As indicated in this narrative, the event had two effects on the local residents' minds. First, it reportedly left them less inclined to simply accept whatever comes from LDS Church headquarters. Second, it motivated them to take action to prevent the destruction of icons of local identity. The narrative of the destruction of the Ephraim Tabernacle is presented as the commencement of local initiative in the development and preservation of heritage. 
Ephraimites have taken several actions to define and preserve their local heritage and identity-a remarkable number of actions, in view of the size of the town. These include publishing traditional and new local folklore, annual heritage festivals, displays of local art and crafts, and historical renovation projects. Finally, perhaps as evidence of the scar left by the destruction of the tabernacle, Ephraimites have placed several structures on national and state registers of historic places, thereby preventing the demolition or even the significant alteration of these buildings' appearance. Together these rituals, sites, and icons articulate the solidary frames discussed by Lindenberg (1998), and thereby sustain the community solidarity already established.

\section{Conclusions}

Simple narratives of community building or community decline are insufficient to characterize community solidarity. Community is sustained through a constant reaffirmation of internal solidarity composed of both behavioral and affective elements; these reinforce each other, potentially indefinitely. This does not lead to a static conception of community, however. Indeed, the most resilient communities are those which are constantly redefined in changing historical circumstances. Research suggests that communities endure most successfully when they articulate a shared value structure and devise ceremonies, icons, and other cultural tools that institutionalize a solidary frame. To work most successfully for the endurance of community, such a frame ought to be defined in terms of long-term goals and yet should be flexible enough to allow for short-term modifications.

On this point we might make comparisons between the Mormon villagers and certain rural-based Anabaptist groups (such as the Amish, the Hutterites, and the Mennonites). All of these groups achieved much of their distinction by withdrawing from the larger society, which was hostile to their religious doctrines and practices. They relocated to distant, rural places, where they expected to avoid pressure to conform to the larger society. As the histories of each of these groups played out on the rural American stage, however, Mormons have distinguished themselves for their resilience in maintaining community, while the other groups have had some difficulty in recent years (Ericksen, Ericksen, and Hostetler 1980; Hartse 1995; Peters 1987).

The Anabaptist groups and the Mormons seem to differ greatly in their views of separation from the social world outside their community. The Mennonites, for example, reject modernization for its own sake (Peters 1987), and separation from the world is a primary belief among the Hutterites (Deets 1939; Hartse 1995). In Mor- 
monism, however, separation from the world is primarily instrumental, not a good in itself.

The millennialist vision of early Mormonism was proclaimed in a statement made originally in 1831, republished several times, and finally canonized. It called for a gathering in preparation for the end of the world, and stated the purposes of this gathering: "Go ye forth unto the land of Zion, that the borders of my people may be enlarged, and that her stakes may be strengthened, and that Zion may go forth unto the regions round about ... ." ("From the Book of Covenants" 1846; "History of Joseph Smith" 1844; "Proclamation" 1841; "Revelations" 1833; Whitmer 1835:191, emphasis added). The intent of the Mormons' withdrawal was to enable the group to return to the world it was leaving; therefore the crossover of broader social institutions with Mormonism does not in itself indicate the demise of Mormon community.

Although social isolation ultimately may not be possible, the Mormon example suggests that local, ethnic, or religious identity need not be dissolved in the continuous pressure of mass society. Even though Mormonism took its adherents into the isolation of the mountains, this isolation always looked outward. Mormonism was committed to establishing and maintaining a homeland beyond the reaches of the world it had left behind, but it also carried a sense of responsibility to return and effect change in the world it rejected. When the world began to encroach on that homeland, the ideological mission was already in place, and it allowed Mormonism to confront that world rather than merely withdraw again.

\section{References}

Allen, A. 1999. The Power of Feminist Theory: Domination, Resistance, Solidarity. Feminist Theory and Politics. Series edited by A. Jaggar and V. Held. Boulder, CO: Westview.

Arrington, L.J. 1958. Great Basin Kingdom: An Economic History of the Latter-day Saints 1830-1900. Cambridge, MA: Harvard University Press.

Brown, R.B., H.R. Geertsen, and R.S. Krannich. 1989. "Community Satisfaction and Social Integration in a Boomtown: A Longitudinal Analysis." Rural Sociology 54:568-86.

Bureau of Economic and Business Research. 1996. Statistical Abstract of Utah: 1996. Salt Lake City: David Eccles School of Business, University of Utah.

Deets, L.E. 1939. "The Hutterites: A Study in Social Cohesion." Ph.D. dissertation, Faculty of Political Science, Columbia University.

Durkheim, E. 1964. The Division of Labor in Society, translated by G. Stimpson. New York: Free Press.

Ericksen, E.E. 1922. The Psychological and Ethical Aspects of Mormon Group Life. Chicago: The University of Chicago Press.

Ericksen, E.P., J.A. Ericksen, and J.A. Hostetler. 1980. "The Cultivation of the Soil as a Moral Directive: Population Growth, Family Ties, and the Maintenance of Community Among the Old Order Amish." Rural Sociology 45:49-68.

Fischer, C.S. 1982. To Dwell Among Friends: Personal Networks in Town and City. Chicago: University of Chicago Press. 
Francaviglia, R.V. 1978. The Mormon Landscape: Existence, Creation, and Perception of a Unique Image in the American West. New York: AMS Press.

"From the Book of Covenants." 1846. Times and Seasons, January 1, p. 1087.

Galpin, C.J. 1924. Rural Social Problems. New York: Century.

Hartse, C. 1995. "Social and Religious Change Among Contemporary Hutterites." Folk 36:109-30.

Hechter, M. 1987. Principles of Group Solidarity. Berkeley: University of California Press.

"History of Joseph Smith." 1844. Times and Seasons, April 15, pp. 496-99.

Hymns of The Church of Jesus Christ of Latter-day Saints. 1985. Salt Lake City: The Church of Jesus Christ of Latter-day Saints.

Lefebvre, H. 1976. "Reflections on the Politics of Space," translated by M.J. Eders. Antipode 8:30-37.

Lindenberg, S. 1998. "Solidarity: Its Microfoundations and Macrodependence. A Framing Approach.” Pp. 61-112 in The Problem of Solidarity: Theories and Models, edited by P. Doreian and T. Fararo. Amsterdam: Gordon and Breach.

Marx, K. and F. Engels. 1970. The German Ideology: Part One with Selections from Parts Two and Three, Together with Marx's "Introduction to a Critique of Political Economy," edited and with introduction by C.J. Arthur. New York: International Publishers.

May, D.L. 1994. Three Frontiers: Family, Land, and Society in the American West, 1850-1900. Cambridge, UK: Cambridge University Press.

Moffat, R.M. 1996. Population History of Western U.S. Cities and Towns, 1850-1990. Lanham, MD: Scarecrow Press.

Nelson, L. N.d. Nelson, Lowry: Papers. Harold B. Lee Library, Brigham Young University, Provo. Unpublished material.

- 1925. A Social Survey of Escalante, Utah. No. 1, Brigham Young University Studies. Provo: Brigham Young University.

-1928. The Utah Farm Village of Ephraim. No. 2, Brigham Young University Studies. Provo: Brigham Young University.

-1930. The Mormon Village: A Study in Social Origins. No. 3, Brigham Young University Studies. Provo: Brigham Young University.

-1933. Some Social and Economic Features of American Fork, Utah. No. 4, Brigham Young University Studies. Provo: Brigham Young University.

- 1952. The Mormon Village: A Pattern and Technique of Land Settlement. Salt Lake City: University of Utah Press.

- 1985. In the Direction of His Dreams: Memoirs. New York: Philosophical Library.

O'Dea, T.F. 1957. The Mormons. Chicago: University of Chicago Press.

Peters, J.F. 1987. "Socialization Among the Old Order Mennonites." International Journal of Comparative Sociology 18:211-23.

Pope, W. and B.D. Johnson. 1983. "Inside Organic Solidarity." American Sociological Review 1983:681-92.

Population Projections for Utah's Cities and Unincorporated Areas. 1997. Salt Lake City: Governor's Office of Planning and Budget.

"Proclamation." 1841. Times and Seasons, December 15, pp. 632-34.

"Revelations." 1833. Evening and Morning Star, May, pp. 89-90.

Shepherd, G. and G. Shepherd. 1986. "Modes of Leader Rhetoric in the Institutional Development of Mormonism." Sociological Analysis 47:125-36.

Stein, M.R. 1972. The Eclipse of Community: An Interpretation of American Studies. Expanded edition. Princeton, NJ: Princeton University Press.

U.S. Department of Commerce. 1990. Census of Population: Social and Economic Characteristics, Utah. Washington, DG: U.S. Department of Commerce, Economics and Statistics Administration, Bureau of the Census.

Whitmer, J. 1835. “Cleanliness.” Messenger and Advocate, September, pp. 187-91. 